\title{
Sekurytyzacja islamu w Azji Centralnej
}

W raz z końcem zimnej wojny i wygaszeniem ideologicznego konfliktu pomiędzy Wschodem a Zachodem to opozycja wobec religijnego ekstremizmu, czy też fundamentalizmu zaczęła stanowić istotny element dyskursu wszelkiej maści reżimów politycznych ${ }^{1}$. Język antyfundamentalistyczny stał się ważnym zasobem legitymizacyjnym dla wielu, często bardzo represyjnych systemów. Ułatwiał im prezentowanie siebie jako umiarkowanych i oświeconych, a swoich przeciwników jako radykałów, fanatyków, czy reakcjonistów. 11 września 2001 r. jedynie wzmocnił tę tendencję, zastępując dyskurs na temat fundamentalizmu ramą terroryzmu islamskiego. Korzystanie z tego języka zapewniało wsparcie dyplomatyczne, militarne, czy materialne. Co więcej, dodatkowo osłabiało siłę międzynarodowej krytyki kierowanej przeciwko tym z krajów autorytarnych, które legitymizowały swoje działania koniecznością walki z terroryzmem islamskim.

Przypadek Azji Centralnej ze względu na charakter systemów politycznych państw regionu, położenie geopolityczne oraz strategiczne interesy supermocarstw, czy też dominującą pozycję islamu, przy wspólnej postradzieckiej przeszłości jest szczególnie interesujący w kontekście wyżej przytoczonych problemów. Jak pisał Adeeb Khalid, w żadnej innej części świata muzułmańskiego dystans pomiędzy państwem a islamem nie był tak wielki jak w Azji Centralnej. Chociaż jest on religią większościową, niemniej był traktowany jako problem, który należy rozwiązać w najlepszym razie drogą biurokratycznej kontroli, w najgorszym, środkami politycznej represji ${ }^{2}$. Celem artykułu jest przedstawienie sposobów konstruowania islamu w dyskursie oraz praktykach niedemokratycznych krajów Azji Centralnej. Cel ten będzie realizowany poprzez odniesienia do teorii sekurytyzacji sytuującej się w ramach paradygmatu konstruktywistycznego. Jak twierdzi artykuł, s. 168 .

A. Khalid, Islam after Communism. Religion and Politics in Central Asia, Berkeley 2007,

2 Ibidem, s. 190. 
przekształcenie różnych przejawów istnienia islamu w homogeniczne zagrożenie dla wielowymiarowo postrzeganego bezpieczeństwa było ważnym posunięciem sekurytyzacyjnym (ang. securitizing move). Znaczenie tego aktu wiązało się z krajowym oraz międzynarodowym poziomem legitymizacji. Jego siła wynika natomiast z siły zasobów autorytarnych elit Azji Centralnej jako dominujących aktorów sekurytyzujących. W pierwszej części tekst wskaże na problemy związane z przekonaniem o radykalizacji muzułmanów w Azji Centralnej i omówi praktyki państw regionu wobec islamu. W kolejnej części wskaże na różne przejawy i wymiary sekurytyzacji islamu w dyskursie i praktyce elit sprawujących władzę w tych krajach.

Teoria sekurytyzacji dobrze wyraża napięcie pomiędzy wymiarem faktów społecznych a dyskursywnych konstrukcji promowanych przez różne grupy w celach legitymizacyjnych. Wiele analiz wskazywało, że sekurytyzacja islamu dokonywana przez elity polityczne krajów Azji Centralnej była raczej elementem autorytarnej polityki, niż racjonalną reakcją na realne problemy związane z terroryzmem islamskim. Najbardziej zdecydowane stanowisko zajmowali David Montgomery i John Heathershaw. Pisali oni o szeregu mitów regulujących sposób myślenia, a w konsekwencji działania elit politycznych tamtych krajów. Analizując dyskurs raportów organizacji pozarządowych (International Crisis Group), wypowiedzi elit politycznych, mediów oraz badań opinii publicznej, autorzy wyróżniali kilka powtarzających się wątków dotyczących islamizacji oraz radykalizacji ${ }^{3}$. Po pierwsze, była to teza o islamizacji jako postradzieckim zerwaniu z przeszłością. Jak podkreślali, ostrość owego zerwania była wyolbrzymiana. Opierała się ona na uproszczonej wizji historii islamu w Azji Centralnej. Zgodnie z nią okres radziecki charakteryzowały przede wszystkim represje oraz zakazy. Miało to spowodować, że po upadku Związku Radzieckiego religia odrodziła się ze zdwojoną, zasilaną chęcią zemsty siłą. W rzeczywistości mimo szeregu ograniczeń nakładanych na praktyki religijne, dane historyczne ujawniają specyficzne współistnienie komunizmu z islamem. Państwo radzieckie podejmowało próby kooptacji religii oraz otwarcia na praktyki religijne przynajmniej od lat 50. Swoją kulminację osiągnęły one w okresie pierestrojki.

3 D.W. Montgomery, J. Heathershaw, Islam, Secularism and Danger: A Reconsideration of the Link Between Religiosity, Radicalism and Rebellion in Central Asia, „Religion, State and Society" 2016, vol. 44, nr 3, s. 196. 
Co więcej, próby znalezienia przez religię swojej pozycji w nowopowstałych państwach zawsze są elementem walki politycznej i niekoniecznie muszą wiązać się radykalizacją.

Drugie z często powtarzanych przekonań utożsamiało islamizację z radykalizacją. Mówiąc inaczej, rosnąca częstotliwość wizyt w meczetach połączona z rosnącym pietyzmem w kultywowaniu religijnej ortodoksji traktowane były jako wstęp do radykalizmu. Takie założenie również było wielokrotnie podważane. Dość wyraźnie pokazują to chociażby szczegółowe badania kwestionariuszowe nad religijnością prowadzone w Kirgistanie (regiony Naryn i Osz) przez D.W. Montgomery'ego. Wśród powodów większej częstotliwości uczestnictwa w praktykach religijnych podawano większą liczbę meczetów, naciski rodziny oraz rówieśników, większą wolność religijną, reakcję na zmiany w społeczeństwie, czy większe rozumienie odpowiedzialności względem Allaha. Jedynie 3\% respondentów wskazało na kryzys polityczny jako powód wizyt w meczecie, a 43\% twierdziło, że modli się więcej niż w okresie radzieckim. Ponadto niewiele ponad jedna trzecia twierdziła, że prawo państwowe powinno odzwierciedlać prawa religijne ${ }^{4}$. Należy jednak pamiętać o, jak ujmują to autorzy, temporalnym raczej niż transcendentalnym charakterze tego stanowiska. Wyraża ono bowiem zaufanie do islamu i nieufność do aktualnej władzy, a nie fundamentalistyczne przekonanie o konieczności politycznej implementacji zasad religijnych ${ }^{5}$. Co więcej, błędem było również aprioryczne traktowanie jako przejawu radykalizacji zjawiska pojawiania się szeregu ugrupowań islamskich. Uznawanie ich za część szerszego ruchu dżihadystycznego nie powinno pomijać faktu, że w wielu przypadkach były to jedyne organizacje zdolne przeciwstawić się hegemonii państwa. Poparcie społeczne dla nich nie zawsze wynikało z motywacji religijnych.

Trzecia krytykowana teza głosiła, że radykalizacja była efektem autorytaryzmu oraz biedy. Brakuje jednak przekonujących danych empirycznych, które potwierdzałyby istnienie tej zależności. Wzmacnianie autorytaryzmu (np. w Tadżykistanie), nie prowadziło do wzrostu siły fundamentalizmu islamskiego. Ponadto badania empiryczne wykazywały, że ruchy dżiha-

4 D.W. Montgomery, Practicing Islam: Knowledge, Experience, and Social Navigation in Kyrgyzstan, Pittsburgh 2016.

5 D.W. Montgomery, J. Heathershaw, op.cit., s. 196. 
dystyczne są problemem w bogatszych regionach świata, niż Azja Centralna. Podobnie rzecz się miała z innymi założeniami obecnymi w mediach, artykułach, czy analizach organizacji pozarządowych. Dyskurs bezpieczeństwa związany z terroryzmem islamskim prowadził również do nadmiernych generalizacji dotyczących radykalizmu tajnych organizacji islamskich, ich rzekomych globalnych powiązaniach, czy też tez o pryncypialnej opozycji pomiędzy islamem a strukturami państwa ${ }^{6}$.

Stanowisko D.W. Montgomery'ego i J. Heathershawa spotkało się z krytyczną odpowiedzią ze strony innych autorów podkreślających wagę zagrożenia dżihadyzmem ${ }^{7}$. Jednak wielu badaczy było zgodnych co do tego, że sekurytyzacja islamu, czy też odwołania do religijnych wątków przy wyjaśnianiu zjawisk terrorystycznych, bądź nawet kryminalnych były istotnym argumentem legitymizacyjnym. Były one wykorzystywane przez autorytarne reżimy dla uzasadniania środków represyjnych.

Christian von Soest i Julia Grauvogel dzielą dyskursy legitymizacyjne pojawiające się w krajach autorytarnych na oparte na wyniku oraz oparte na tożsamości. W tym pierwszym typie ważną rolę odgrywały wszelkiego rodzaju narracje oparte na odwołaniach do bezpieczeństwa obywateli oraz stabilności państwa. Jak ustalili, legitymizacja oparta na wyniku była szczególnie istotna w wielu republikach centralnoazjatyckich. Niektóre z nich odwoływały się do zdolności do zapewniania własnym obywatelom darmowej wody i elektryczności (np. Turkmenistan), inne do stabilności oraz bezpieczeństwa (np. Tadżykistan, Uzbekistan) ${ }^{8}$.

$\mathrm{Z}$ kolei Mariya Omelicheva analizowała dyskursywne reprezentacje islamu w Kazachstanie oraz Uzbekistanie w oparciu o przemówienia prezydentów oraz dyskurs medialny. Według niej, przedstawianie islamu jako

6 Ibidem, s. 202-207.

7 E. Karin, The Soldiers of the Caliphate: The Anatomy of a Terrorist Group, Astana 2016; S. Lain, Strategies For Countering Terrorism and Extremism in Central Asia, "Asian Affairs” 2016, vol. 47, nr 3, s. 386-405; A. Masylkanova, Radicalization in Kyrgyzstan is no Myth: Kyrgyzstan's Slow Arc Toward Islamization and Radicalization, „The Diplomat”, 22.06.2016; A. Matveeva, Radicalisation and Violent Extremism in Kyrgyzstan. On the Way to the Caliphate? „The RUSI Journal" 2018, vol. 163, nr 1, s. 30-46.

8 C. von Soest, J. Grauvogel, Identity, Procedures and Performance: How Authoritarian Regimes Legitimize their Rule, "Contemporary Politics” 2017, vol. 23, nr 3, s. 289; na temat korzystania przez rządzących z wątków nacjonalistycznych zob. też V. Bunce, S. Wolchik, Defeating Dictators: Electoral Change and Stability in Competitive Authoritarian Regimes, „World Politics" 2010, s. 2010, s. 61. 
zagrożenia było jednym z istotnych sposobów autoprezentacji władzy jako jedynej zdolnej do zabezpieczenia miejscowej ludności przed bojownikami islamskimi. Figura radykalnego islamu była również instrumentalizowana w ramach argumentacji dotyczącej problemów społeczno-ekonomicznych. Wówczas to zagrożenie islamem uzasadniało na przykład brak państwowych programów społecznych ${ }^{9}$.

Do analizy powyższego zjawiska szczególnie adekwatna wydaje się teoria sekurytyzacji rozwijana w ramach tzw. szkoły kopenhaskiej ${ }^{10}$. Ta reprezentująca paradygmat konstruktywistyczny koncepcja zakłada, że dane kwestie stają się problemami, czy też zagrożeniami bezpieczeństwa za pośrednictwem języka. Bezpieczeństwo nie jest stanem rzeczy niezależnym od ludzkich sądów na jego temat. Jest ono raczej pochodną społecznych i politycznych procesów definiowania. Dotyczy sytuacji, w których „dana kwestia jest prezentowana jako stwarzająca egzystencjalne zagrożenie dla obiektu odniesienia (tradycyjnie, ale niekoniecznie państwa, włączając w to rząd, terytorium oraz społeczeństwo)" ${ }^{11}$. W tym sensie język konstytuuje bezpieczeństwo, a nie po prostu odzwierciedla empirycznie występujący stan rzeczy. Jak pisze Ole Wæver, „korzystając z teorii języka, możemy rozpatrywać «bezpieczeństwo» jako akt mowy. W takim rozumieniu, bezpieczeństwo nie jest po prostu znakiem, który odnosi się do czegoś bardziej realnego, ale samo wypowiedzenie jest działaniem. [...] Poprzez wypowiedzenie kategorii «bezpieczeństwo», przedstawiciel państwa wprowadza określoną kwestię w pole [zagrożenia -N.S.], tym samym domagając się specjalnego prawa do

9 M.Y. Omelicheva, Islam and Power Legitimation: Instrumentalisation of Religion in Central Asian States, „Contemporary Politics” 2016, vol. 22, nr 2, s. 157.

10 O teorii sekurytyzacji pisali również K. Marczuk, Bezpieczeństwo wewnętrzne w poszerzonej agendzie studiów nad bezpieczeństwem (szkoła kopenhaska i human security), [w:] Bezpieczeństwo wewnętrzne państwa: wybrane zagadnienia, red. S. Sulowski, M. Brzeziński, Warszawa 2009; Ł. Fijałkowski, Teoria sekurytyzacji i konstruowanie bezpieczeństwa, „Przegląd Strategiczny” 2012, nr 1; Ł. Fijałkowski, „Akt mowy” $i$ „język bezpieczeństwa” a konstruowanie globalnych zagrożeń (dyskursywne podejście do bezpieczeństwa), „Kultura - Historia - Globalizacja” 2013, nr 14; J. Szalacha, W. Sokołowicz, Sekurytyzacja jako paradygmat w badaniach nad bezpieczeństwem oraz proces polityczny. Koncepcja i konteksty, [w:] Za kulisami Szkice o wtadzy, interesach i bezpieczeństwie, red. K. Pietrowicz, P. Stankiewicz, Poznań 2013; M. Musioł, Kompleks Bezpieczeństwa w regionie Azji Środkowej po 1991 roku, Warszawa 2015; M. Musioł, Znaczenie sekurytyzacji i sektorów bezpieczeństwa w ramach krytycznych studiów nad bezpieczeństwem, „Historia i Polityka” 2018, nr 23 (30).

11 B. Buzan, O. Wæver, J. de Wilde, Security: A New Framework for Analysis, London 1998, s. 21. 
użycia jakichkolwiek środków koniecznych do jej zablokowania"12. To język jest więc instrumentem przedstawiania określonych kwestii bądź aktorów jako egzystencjalne zagrożenie dla określonej wspólnoty. Pociąga to za sobą sekurytyzację. Barry Buzan i O. Wæver definiują sekurytyzację jako „dyskursywny proces, w toku którego konstruowane jest w ramach wspólnoty politycznej intersubiektywne porozumienie co do traktowania czegoś jako egzystencjalnego zagrożenia dla cenionego obiektu odniesienia. Uzasadnia to zastosowanie natychmiastowych i wyjątkowych środków do rozprawienia się z zagrożeniem"13.

Sekurytyzacja jest więc procesem, który składa się z kilku etapów. Po pierwsze, sekurytyzujący aktor (np. państwo, elita, lobby) konstruuje obiekt odniesienia (np. tożsamość, suwerenność, integralność terytorialna) oraz dyskurs zagrożenia egzystencjalnego dla obiektu odniesienia. Następnie za pośrednictwem aktu mowy przedstawia odbiorcom (np. opinii publicznej, politykom, społeczeństwu) narrację o istniejącym zagrożeniu. Odwołując się do potrzeby przetrwania wskazuje on na konieczność zastosowania środków wyjątkowych, wykraczających poza konwencjonalne reguły gry politycznej. Zjawisko to określa się mianem posunięcia sekurytyzującego. Ostatnim etapem jest reakcja odbiorców na posunięcia aktorów sekurytyzujących. Jeśli zostaną one zaakceptowane uznaje się, że miał miejsce skuteczny proces sekurytyzacji. Tym samym teoria sekurytyzacji wyjaśnia, nie tylko jak za pośrednictwem dyskursów o bezpieczeństwie implementowane są środki wyjątkowe, ale i jak w tym celu różni aktorzy mobilizują odbiorców. Akceptacja odbiorców jest szczególnie istotna w przypadku krajów demokratycznych. Bez niej mamy do czynienia jedynie z posunięciem sekurytyzacyjnym podmiotów politycznych, który nie ma wpływu na praktyki bezpieczeństwa państwa. Celem teorii sekurytyzacji jest zrozumienie kto sekurytyzuje, jakie kwestie przedstawiane są jako zagrożenia, kto lub co jest obiektem odniesienia, a także dlaczego, z jakim efektem oraz w jakich warunkach te procesy mają miejsce ${ }^{14}$. Prezentowana teoria opiera się więc na następujących elementach: akcie mowy, sekurytyzujących aktorach, od-

12 O. Wæver, Securitization and Desecuritization, [w:] On Security, red. R.D. Lipschutz, New York 1995, s. 55.

13 B. Buzan, O. Wæver, Regions and Powers: The Structure of International Security, Cambridge 2003, s. 491.

14 B. Buzan, O. Wæver, J. de Wilde, op.cit., s. 32. 
biorcach oraz warunkach sprzyjających, które wpływają na sukces sekurytyzacyjnych posunięć.

Obiektem odniesienia dla sekurytyzacji może być wiele zjawisk, czy podmiotów. Aktorzy mogą, w zasadzie, podjąć próbę sekurytyzacji czegokolwiek. W praktyce jednak ich możliwości nie są nieograniczone. Przedstawiciele szkoły kopenhaskiej wskazują na istnienie warunków sprzyjających sekurytyzacji, co ma szczególne znaczenie w przypadku krajów autorytarnych ${ }^{15}$. Pośród nich za ważną należy uznać pozycję aktora sekurytyzującego oraz właściwości danego zjawiska przedstawianego jako zagrożenie. Z kolei Thierry Balzacq stwierdza, że siła aktu mowy uzależniona jest od kilku czynników. Po pierwsze, od kontekstu oraz pozycji władczej podmiotu wypowiadającego, trafności wypowiedzi wreszcie wykorzystywanych strategii dyskursywnych. Oczywiście żaden z nich z osobna nie rozstrzyga o sukcesie sekurytyzacji. Wzięte jednak razem mają wpływ na skuteczność sekurytyzacyjnych przedsięwzięć elit ${ }^{16}$.

W państwach Azji Centralnej żadna tożsamość nie była w stanie zapewnić autentycznej jedności narodowej, a idea narodu (w rozumieniu etnicznym - ekskluzywnym, bądź obywatelskim - inkluzywnym) konkurowała z innymi rodzajami samoidentyfikacji. Na dodatek, omawiane państwa wykazywały, choć w różnym stopniu, słabą formalizację relacji społeczno-politycznych ${ }^{17}$. Prezydenci, mając niewielką bazę społecznego poparcia, swoją władzę opierali na wąskim kręgu zwolenników (Kirgistan, Kazachstan ${ }^{18}$ ) i resortach siłowych (Uzbekistan, Tadżykistan, Turkmenistan). Ograniczenie wolności słowa oraz wielość zasobów znajdujących się w rękach elity rządzącej ustanawiały silnie asymetryczną relację. Tym samym możliwe było sprawowanie kontroli nad dyskursem bezpieczeństwa. Rozbudowie aparatu represyjnego, towarzyszył jednak rozkład odziedziczonych

15 Ibidem, s. 36.

16 T. Balzacq, A Theory of Securitization: Origins, Core Assumptions, and Variants, [w:] Securitization Theory. How Security Problems Emerge and Dissolve, red. T. Balzacq, New York 2011, s. 26.

17 N. Shukuralieva, Azja Centralna: uwarunkowania integracji regionalnej, [w:] Relacje Unii Europejskiej z Azją Centralną. Uwarunkowania, wyzwania, efekty, red. T. Wallas, R. Fiedler, Poznań 2018, s. 207-223.

18 Patrz szerzej N. Shukuralieva, A. Lipiński, Legitymizacja władzy jako wielowymiarowy mechanizm stabilizacji systemu autorytarnego. Casus państw Azji Centralnej. [w:] Azja Centralna: tożsamość, naród, polityka, red. N. Shukuralieva, Kraków 2018, s. 15-35. 
po ZSRR instytucji państwowych. Głęboko skorumpowane i niewydolne w czasach niepodległości działały one raczej jak forum, na których podmioty subpaństwowe konkurowały ze sobą, aby zapewnić sobie bezpieczeństwo oraz wpływ na państwo.

Z wyjątkiem upolitycznionego Kirgistanu bardzo rzadko dochodziło do niereżyserowanych przez władzę pokojowych zgromadzeń. Jeśli już, to ich uczestnicy podnosili kwestię samowoli resortów siłowych, czy organów państwowych. Większość społeczeństwa natomiast wykazywała nastroje apatii i uzależnienia od kaprysu władzy ${ }^{19}$. Konsolidacja systemu autorytarnego wymagała wzmocnienia struktur władzy oraz uzasadnienia coraz szerszych form ograniczenia swobód politycznych i gospodarczych. We wszystkich omawianych państwach, aczkolwiek w różnym natężeniu, odbywało się to m.in. za pomocą sekurytyzacji islamu. Czynniki ułatwiające przesuwanie kwestii wiary i praktyk religijnych do sfery bezpieczeństwa można zidentyfikować w dwóch wymiarach.

Po pierwsze, w wymiarze międzynarodowym sekurytyzacyjne zabiegi artykułowane były za pośrednictwem akceptowanego przez międzynarodową społeczność dyskursu wojny z terroryzmem. Warto zaznaczyć, że kształt środowiska międzynarodowego Azji Centralnej był silnie determinowany działaniami mocarstw światowych. Polityka Stanów Zjednoczonych po wydarzeniach z 11 września 2001 r. oraz aktywność działającej pod przywództwem USA koalicji antyterrorystycznej stwarzały szczególne warunki do opracowania nowego dyskursu bezpieczeństwa międzynarodowego. Walka $\mathrm{z}$ międzynarodowym terroryzmem i islamskim fundamentalizmem odgrywały w nim kluczowe znaczenie. W rezultacie posługiwanie się w dyskursie politycznym rządów krajów autorytarnych argumentami zagrożeń płynących z terroryzmu islamskiego oraz prowadzenie pod tym szyldem walki z przeciwnikami politycznymi zyskiwało uprawomocnienie społeczności międzynarodowej ${ }^{20}$.

19 A. Matveeva, Tajikistan: Revolutionary Situation or a Resilient state? „EUCAM Policy Brief” 2009, nr 12; Tajikistan 2017 Human Rights Report. Executive Summary, U.S. State Department. Bureau of Democracy, Human Rights, and Labor, Washington 2018; International Partnership for Human Rights, The Danger of Standing up for Justice and Rights in Central Asia. Trends regarding the Protection of Civil Society in the Region in 2017, Brussels 03.2018.

20 И. Черных, Р. Бурнашев, Условия секьюритизации международного терроризма в Центральной Азии, „Connections. The Quarterly Journal” 2005, t. 4, nr 1, s. 172. 
Po drugie, Azja Centralna ze względu na sąsiedztwo z Afganistanem, gdzie przebiegały działania wojenne zachodniej koalicji, została wciągnięta w tzw. wojnę z międzynarodowym terroryzmem. Stany Zjednoczone (w Uzbekistanie i Kirgistanie), Niemcy (w Uzbekistanie) i Francja (w Tadżykistanie) otrzymały zgodę na korzystanie z przestrzeni powietrznej i rozmieszczenie swoich kontyngentów wojskowych służących do wsparcia działań w Afganistanie. Stąd też kraje Zachodu nie tylko zawiesiły krytykę oszustw wyborczych, ograniczania praw i wolności obywatelskich czy tłumienia opozycji. Podejmowały one także kroki, które sprzyjały wzmocnieniu lokalnych reżimów autorytarnych ${ }^{21}$. Były nim oficjalne spotkania z władzami państw Azji Centralnej, przychylne komentarze dotyczące prowadzonej przez nie polityki, wsparcie finansowe i wzmocnienie ich resortów siłowych.

Należy zaznaczyć, że w Azji Centralnej sekurytyzacja islamu nie mogła przebiegać w oderwaniu od wartości wyznawanych przez stanowiącą ponad 85\% społeczność muzułmańską. Państwa regionu ogłosiły oficjalnym świętem państwowym Id al-Adha (Kurban Bajram) oraz Id al-Fitr (Ramadan Bajram), były członkami Organizacji Współpracy Islamskiej, zaciągały pożyczki z Islamskiego Bank Rozwoju, aktywnie próbowały także zacieśnić współpracę z państwami, gdzie islam odgrywał dużą rolę. Stąd też ilościowa analiza przemówień prezydentów nie wykazałaby wysokiej częstotliwości słowa „islam” o negatywnej konotacji. Wręcz przeciwnie, przywódcy analizowanych państw podkreślali zazwyczaj, że jest on religią pokoju, miłości, wiedzy i moralności' ${ }^{22}$. Wielokrotnie potępiali również wzrost antyislamskich nastrojów u swoich zachodnich sojuszników. Wedle prezydenta Tadżykistanu Emomali Rahmona ONZ oraz OBWE powinny podjąć zdecydowane kroki, aby zapobiec takim tendencjom. De-

21 N. Shukuralieva, Bezpieczeństwo międzynarodowe, terroryzm i zasoby naturalne. Międzynarodowa legitymizacja władzy w Azji Środkowej, „Sprawy Międzynarodowe” 2013, nr 4, s. 56-59.

22 Patrz nр.: Э. Рахмонов, Поздравиение со священным месяцем Рамазан. 24.10.2003, [w:] Э. Рахмонов, Независимость Таджикистана и возрождение нации, t. 5, Аушанбе 2006, s. 237-238; Э. Рахмонов, ПозАравление по случаю праздника ИАи Фитр. 24.11.2003, [w:] Э. Рахмонов, Независимость..., ор.cit., t. 5, s. 249; Э. Рахмонов, Выступцение на Аесятом саммите Организации Исламской Конференции. Куала-Аумпур (Малайзия) 15-19.10.2003, [w:] Э. Рахмонов, Независимость ..., ор.cit., t. 5, s. 229; Н.Ә. Назарбаев, СынАарлы он жыц, Алматы 2003, s. 32. 
monizowanie islamu, czynienie z niego wroga cywilizacji oraz upatrywanie w nim źródeł terroryzmu miało być niebezpieczną grą prowadzoną przez wpływowych międzynarodowych aktorów i mogło doprowadzić do katastrofalnych skutków ${ }^{23}$. Rachmon podkreślał również, że islam nie tylko nie ma nic wspólnego z terroryzmem i ekstremizmem, ale przeciwnie, potępia te niepożądane i niebezpieczne zjawiska ${ }^{24}$.

Powyższa narracja była elementem konstruowanego przez prezydentów podziału dychotomicznego. $\mathrm{Z}$ jednej strony mamy w niej do czynienia z pozytywnym, zdrowym, tradycyjnym, oświeconym, tolerancyjnym, rodzimym islamem ${ }^{25}$, który jest „przeniknięty duchem naszej cywilizacji ${ }^{26}$. W tej wizji dobry muzułmanin miał być lojalnym, posłusznym obywatelem, który bezkrytycznie popiera posunięcia władzy. Stąd podkreślano konieczność zachowania islamu, okazania wsparcia muzułmanom, ale i obrony przed zewnętrzną ingerencją. Z drugiej jednak strony islam był reprezentowany jako obcy, zagraniczny element o destrukcyjnym potencjale. Osoby przypisane do tej kategorii miały być członkami zakazanych, zazwyczaj „terrorystycznych organizacji, które podszywając się pod pseudoreligijne hasła, jak to czyni słynny Hizb ut-Tahrir, podejmowały nieludzkie, barbarzyńskie działania"27. Jeśli początkowo wpływy obcego islamu miały wywodzić się z Afganistanu, to później wskazywano także

23 Э. Рахмонов, Воспитывать человека, гражданина, патриота. Речь на встрече с преАставителями интелмигенции страны, 20.03.2004, [w:] Э. Рахмонов, Независимость..., op.cit., t. 5, s. 312.

24 Э. Рахмонов, Поздравление со священным месяцем Рамазан..., ор.cit., t. 5, s. 237-238; Э. Рахмонов, Воспитывать человека..., ор.cit., s. 312; Э. Рахмонов, Нам нужен стабильный Афганистан. Интервью с корреспондентом „Независимой газеты” 1910.2001, [w:] Э. Рахмонов, Независимость..., ор.cit., t. 4, s. 195.

25 И.А. Каримов, Империя даврида бизни иккинчи даражахи одамлар, деб хисоблашар эди. «Независимая газета» (Москва) мухбирининг савомларига жавоблар. 14.01.2005, [w:] И.А. Каримов, Ўзбек халқи хеч қачон, хеч кимга қарам бўлмайди, Ж. 13. Тошкент 2005, s. 149-150; Э. Рахмонов, Связь веков - преемственность поколений. АоклаА в честь Авенадцатой годовщины независимости Республики Таджикистан и 1000-летия великого таджикского поэта и мыслитемя Носира Хусрава. 8.09.2003, [w:] Э. Рахмонов, Независимость ..., ор.cit., t.5, s. 207.

26 Э. Рахмонов, Связь веков..., ор.cit., s. 207.

27 И.А. Каримов, Ўзбекистон хитойнинг ишончли Аўсти ва хамкори бўлган, бунАан кейин хам шундай бўлиб қолаАи. Хитой Халқ Республикасига Аавлат ташрифи муносабати билан „Жэньминь Жибао” газетаси мухбирига беримган интервью, 25.05.2005, [w:] И.А. Каримов, Ўзбек халқи..., ор.cit., s. 432; И.А. Каримов, Империя даврида..., ор.cit. s. 149-150. 
na Arabię Saudyjską, Pakistan, czy Islamskie Państwo w Iraku i Lewancie. Podkreślić należy, że akcentowanie zagranicznego rodowodu umożliwiało abstrahowanie od wewnętrznych przyczyn i warunków ich występowania ${ }^{28}$.

W sytuacji, w której udana konstrukcja zagrożenia legitymizuje korzystanie z wyjątkowych, represyjnych środków i sposobów działania, ten mechanizm był szczególnie istotny dla autorytarnych przywódców. Niezależnie bowiem od typu reżimu politycznego rządzący poszukują różnych sposobów usprawiedliwienia działań ograniczających prawa i wolności obywateli. Represje raczej przedstawiane są jako konieczność związana z zagrożeniem dla ładu i porządku, niż nie wymagający żadnych wyjaśnień akt wynikający z własnej pozycji władczej ${ }^{29}$. Juha Vuori zauważa z kolei, że sekurytyzacja może również, obok funkcji legitymizacyjnej, pełnić funkcję wprowadzania na agendę, kontroli czy też odstraszania ${ }^{30}$.

Szkoła kopenhaska wskazuje na pięć ogólnych sektorów oraz odpowiadających im typów bezpieczeństwa: militarnego, politycznego, ekonomicznego, społecznego oraz środowiskowego. Aktorzy sekurytyzujący (często państwo) wyznaczają w odniesieniu do każdego z nich typowe obiekty odniesienia. Szczególnie interesujące w przypadku analizowanego tematu są sposoby konstrukcji islamu jako zagrożenia. W wypowiedziach publicznych prezydentów państw Azji Centralnej figura islamu jako zagrożenia używana była w celach sekurytyzacyjnych w ramach trzech sektorów.

Tabela 1. Dynamika sekurytyzacji a sektory bezpieczeństwa

\begin{tabular}{|l|l|l|}
\hline \multicolumn{1}{|c|}{ Sektor } & \multicolumn{1}{|c|}{ Rodzaj interakcji } & \multicolumn{1}{c|}{ Dynamika sekurytyzacji } \\
\hline Militarny & Relacje oparte na przymusie & $\begin{array}{l}\text { Egzystencjalne zagrożenie dla państwa/ludności/ teryto- } \\
\text { rium/możliwości wojskowych }\end{array}$ \\
\hline Polityczny & $\begin{array}{l}\text { Relacje oparte na władzy, rzą- } \\
\text { dzeniu, uznaniu }\end{array}$ & $\begin{array}{l}\text { Egzystencjalne zagrożenie dla suwerenności/stabilności } \\
\text { porządku społecznego }\end{array}$ \\
\hline
\end{tabular}

28 И. Черных, Р. Бурнашев, ор.cit., s. 173.

29 C. Davenport, Repression and Mobilization: Insights from Political Science and Sociology, [w:] Repression and Mobilization, red. C. Davenport, C. Mueller, H. Johnston, Minneapolis-London 2005, s. XV.

30 J.A. Vuori, Illocutionary Logic and Strands of Securitization: Applying the Theory of Securitization to the Study of Non-Democratic Political Orders, „European Journal of International Relations" 2008, t. 14, nr 1, s. 76. 


\begin{tabular}{|l|l|l|}
\hline Ekonomiczny & $\begin{array}{l}\text { Relacje oparte na handlu, pro- } \\
\text { dukcji i finansach }\end{array}$ & Egzystencjalne zagrożenie dla rynków/finansów/zasobów \\
\hline Społeczny & $\begin{array}{l}\text { Relacje oparte na kolektywnej } \\
\text { tożsamości }\end{array}$ & $\begin{array}{l}\text { Egzystencjalne zagrożenie dla kolektywnej tożsamości/ję- } \\
\text { zyka/kultury }\end{array}$ \\
\hline Środowiskowy & $\begin{array}{l}\text { Relacje między aktywnościąą } \\
\text { ludzką a ziemską biosferą }\end{array}$ & $\begin{array}{l}\text { Egzystencjalne zagrożenie dla biosfery/gatunków/środo- } \\
\text { wiska naturalnego }\end{array}$ \\
\hline
\end{tabular}

Źródło: C. Peoples, N. Vaughan-Williams, Critical Security Studies. An introduction, London-New York 2010, s. 80.

Po pierwsze, był to sektor militarny. Argumenty o islamskim radykalizmie jako zagrożeniu dla przetrwania państwa, ludności, integralności terytorialnej, czy możliwości wojskowych były obecne we wszystkich omawianych państwach. Najbardziej intensywnie występowały one jednak w Tadżykistanie i Uzbekistanie. Atak z 11 września 2001 r. na terytorium USA, a w efekcie rozpoczęcie operacji wojskowych przez zachodnią koalicję oraz zmiana międzynarodowego dyskursu bezpieczeństwa zostały przyjęte przez prezydenta Uzbekistanu Islom Karimova ${ }^{31}$ oraz prezydenta Tadżykistanu Emomali Rahmona $^{32}$ jako nieco spóźnione potwierdzenie słuszności prowadzonej przez nich dotąd polityki. Co więcej, pozwoliło im to na zastąpienie dotychczasowej roli nieudolnego ucznia demokracji, pozycją kompetentnego eksperta. Doświadczenia wojny domowej (przypadek Tadżykistanu) oraz brutalnego tłumienia wszelkich przejawów opozycji miały z nich czynić autorytety, którym udaje się powstrzymywać zagrożenie islamskiego ekstremizmu. Wedle słów E. Rahmona: „jednak wielu jeszcze nie zdało sobie sprawy z prawdziwego zagrożenia i możliwości terroryzmu. W sytuacji, gdy opinia publiczna na świecie dowiedziała się o podstępnych działaniach terroryzmu, konieczne jest podjęcie wszelkich działań w celu zapewnienia bezpieczeństwa całej planecie. Aktualne wydarzenia i rozprzestrzenianie się międzynarodowego terroryzmu na świecie zmusiły wiele krajów świata do wyboru tej właśnie

31 И.А. Каримов, Бизнинг бош мақсадимиз - жамиятни демократлаштириш ва янгимаш, мамлакатни модернизация ва ислох этишАир. Ўзбекистон Республикаси Олий Маж-

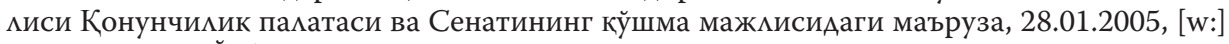
И.А. Каримов, Ўзбек халқи..., ор.cit., s. 200-201.

32 Э. Рахмонов, Великий поэт и видный общественный деятель. Выступление на торжественном собрании, посвящённом 90-летию со Аня рожАения устода Мирзо Турсун-Заде. Аушанбе 27.10.2001, [w:] Э. Рахмонов, Независимость ..., ор.cit., t. 4, s. 208; Э. Рахмонов, Экстремизм не пройдёт. Интервью с корреспондентом журнала „Микцениум” 10.2001, nr 10, [w:] Э. Рахмонов, Независимость ..., ор.cit., t. 4, s. 213. 
ścieżki”33. Powyższa narracja, dość typowa dla władz regionu, umieszczała przejawy kontestacji władzy w państwach Azji Centralnej w szerszym, międzynarodowym kontekście. W ten sposób przedstawiano np. wydarzenia w Andiżanie z 2005 r. Wedle I. Karimova „w najbardziej bezczelny sposób rozstrzeliwano żołnierzy, zorganizowano bezprecedensowy atak na jednostkę wojskową, przejęto dziesiątki karabinów maszynowych, zajęto budynek regionalnego hokimiatu” oraz dokonano „próby obalenia ustroju konstytucyjnego" ${ }^{34}$. Tak w tym, jak i w wielu innych przypadkach, gdzie resorty siłowe krwawo tłumiły akcje protestacyjne, wybuchy protestów były interpretowane jako działania międzynarodowych terrorystów. Wedle powyższego, oficjalnego dyskursu konspiracyjna i związana z użyciem przemocy aktywność miały na celu obalenie panującej władzy, podważanie integralności terytorialnej oraz zastąpienie świeckiego charakteru państwa Kalifatem.

Po drugie, był to sektor polityczny. Odnosił się on do wątków, w których islamski radykalizm zagrażał suwerenności państwa, jego instytucjom i stabilności porządku społecznego. Przejawem tego typu sekurytyzacji było traktowanie z wielką podejrzliwością aktorów odwołujących się do wartości religijnych w ramach rywalizacji politycznej. Ponadto, uchwalono akty prawne (np. ustawy o partiach politycznych ${ }^{35}$ ) wprowadzające zakaz tworzenia partii politycznych na tle religijnym, co całkowicie wykluczało je z legalnej przestrzeni politycznej. Argumentowano, że przenikające z zagranicy „religijno-ekstremistyczne i radykalne elementy polityczne wzywają do obalenia istniejącej władzy, ustanowienia archaicznych reżimów lub uzyskania autonomii w niektórych regionach kraju" ${ }^{36}$. Zgodnie z oficjalną linią sama wspólnota muzułmańska pozbawiona ścisłej kontroli organów państwowych mogła również stanowić egzystencjalne zagrożenie dla stabilno-

\footnotetext{
33 Э. Рахмонов, Великий поэт..., ор.сіt., s. 208.

34 И.А. Каримов, Бизни танлаган йўлимиздан хеч ким қайтаролмайди. Шу йилнинг 12-13 май кунлари Андижон шахриАа рўй берган воқеалар муносабати билан махамлий ва хорижий оммавий ахборот воситалари учун ўтказилган матбуот анжуманиАаги баёнот ва мухбирларнинг савоммарига жавоблар, [w:] И.А. Каримов, Ўзбек халқи..., ор.сіt., s. 338-339.

35 Nр.: Ўзбекистон Республикасининг 26.12.1996 й. 337-I-сон „Сиёсий партиялар тўғрисида”ги Қонуни, „Народное слово”, 7.01.1997, № 4 (1527); „Саяси партиямар турахы” Қазақстан Республикасының 2002 жылғы 15 шілдедегі № 344-II Заңы; Кыргыз Республикасынын 12.06.1999 № 50 „Саясий партиякар жөнүндө” мыйзамы, „Эркин-Тоо”, 25.06.1999.

36 Н.Ә. Назарбаев, ор.cit., s. 59.
} 
ści porządku społecznego. Część z nich potencjalnie mogła, bądź faktycznie już „znajdowała się pod wpływem misjonarzy z zagranicznych ośrodków islamskich" ${ }^{37}$. Choć w różnym stopniu, we wszystkich omawianych państwach obecność islamu w przestrzeni politycznej budziła niepokój. Jak wielokrotnie powtarzali w swoich wystąpieniach publicznych prezydenci, wpływy zagranicznego islamu miały kształtować ideologię „nietolerancji religijnej”"38, „nienawiści i terroryzmu” 39 i prowadzić do „zwiększonych napięć, rodzić nieufność, podziały i lęk” ${ }^{40}$, co w konsekwencji mogło „doprowadzić do nieładu w społeczeństwie"

Po trzecie, był to sektor społeczny. Dyskurs odnoszący się do tego sektora obejmował wątki, w których islamski radykalizm zagrażał zbiorowej tożsamości, językowi i kulturze. Lokalne władze próbując zapewnić sobie monopol w konstruowaniu tożsamości narodowej były świadome, że konkurują z o wiele silniejszym przeciwnikiem - tożsamością religijną. Z niepokojem odnotowywały wzrost liczby meczetów, medres (teologicznych szkół muzułmańskich) oraz osób, które otrzymały zagraniczne wykształcenie. Wedle prezydenta Tadżykistanu E. Rahmona dziesiątki młodych mężczyzn ucząc się w medresach różnych państw islamskich, w rzeczywistości przechodziły szkołę terroryzmu. Na dodatek gwałtowne nasilenie oddolnych inicjatyw budowy meczetów, w którym nie uczestniczyło państwo, lecz bogaci darczyńcy, rodziło wiele spekulacji ${ }^{42}$. Twierdzono, że religijni misjonarze i organizacje pod przykrywką „czystego” islamu narzucały rdzennym mieszkań-

\footnotetext{
37 Ibidem.

38 Ibidem.
}

39 И.А. Каримов, Бизнинг бош мақсадимиз - жамиятни демократлаштириш ва янгимаш, мамлакатни модернизация ва ислох этишдир. Ўзбекистон Республикаси Олий Мажмиси Қонунчимик палатаси ва Сенатининг қўшма мажлисиАаги маъруза, 28.01.2005, [w:] И.А. Каримов, Ўзбек халқи..., ор.cit., s. 200-201.

40 А. Атамбаев, Светтик мамкекеттин артыкчылыгы - түрАүҮ Аиний жамааттарАын өкүлдөрүнүн, Аин туткандар менен эч кандай Аинди тутпагандардын кызыкчылыктарын тең салмакта сактай билгендигинде. „Ислам азыркы светтик мамлекетте” эл арамык конференциясында сүйлөгөн сөзү. 28.09.2017, http://www.president.kg/kg/okujalar/ zhanylyktar/10946_prezident_almazbek_atambaev_svettik_mamlekettin_artikchiligi_trd_ diniy_ghamaattardin_kldrnn_din_tutkandar_menen_ech_kanday_dindi_tutpagandardin_kizikchiliktarin_te_salmakta_saktay_bilgendiginde [dostęp: 11.11.2018].

41 Э. Рахмонов, Связь веков..., ор.cit., s. 207.

42 Э. Рахмонов, Пианирование семьи - залог стабильного ее развития. Речь на общереспубликанском собрании по пробцемам демографического развития и планирования семьи, Аушанбе, 20.02.2002, [w:] Э. Рахмонов, Независимость ..., ор.cit., t. 4, s. 258. 
com obcy styl życia i elementy kulturowe ${ }^{43}$. W opinii prezydenta Kirgistanu Almazbek Atambajewa zagrażało to nie tylko różnorodności kulturowej wieloetnicznej wspólnoty, ale i odradzającej się kirgiskiej tożsamości narodowej $^{44}$. „W sytuacji, gdy kierując się religią będziemy sukcesywnie zatracać swoje bogactwo duchowe, stopniowo przestaniemy już być narodem. [...] Jeśli my Kirgizi będziemy się arabizować, pakistanizować, czy przyjmować jakieś inne, obce zwyczaje, mówić ich językiem, nosić ich ubrania, to wówczas zatracimy swoje korzenie i przestaniemy istnieć jako narodowość"45. Kwestie wplatania do wypowiedzi nowych, arabskich słów, zakładania charakterystycznych ubrań, takich jak abaja, hidżab, czy specyficznej (wyraźnie różniącej się od lokalnych) metody zawiązywania chusty, zapuszczanie brody i noszenie przykrótkich, czy zbyt szerokich spodni przez młodych mężczyzn niepokoiło władze państw Azji Centralnej. Choć zapewnienie bezpieczeństwa w sektorze społecznym było realizowane w różnoraki sposób (jak np. kryminalizacja długiego zarostu męskiego, zakaz noszenia chusty, przymus noszenia strojów ludowych), ich wspólną cechą była represyjność. W wielu przypadkach służyły jako pretekst dla przedstawicieli organów państwowych i resortów siłowych do ingerencji w życie prywatne obywateli, zatrzymań, aresztów, stosowania tortur, a co za tym idzie - otwierały przestrzeń dla korupcji.

Zadaniem niniejszego tekstu było pokazanie sposobów konstruowania islamu w państwach Azji Centralnej. W tym celu przywołano przykłady związane z polityką religijną, akty prawne oraz przemówienia publiczne elity władzy. Umieszczenie analizy w perspektywie teorii sekurytyzacji umożliwiło wyeksponowanie napięcia pomiędzy wymiarem faktów społecznych, a dyskursywnych konstrukcji panującej władzy. Zgodzić się należy z tezą wielu badaczy, że sekurytyzacja islamu była raczej elementem autorytarnej polityki, niż racjonalną reakcją na realne problemy związane z terroryzmem, radykalizmem, czy fundamentalizmem islamskim.

43 А. Атамбаев, Светтик мамлекеттин..., ор.cit.

44 Ibidem.

45 А. Атамбаев, Аиний чөйрөдө абийир эркиндигинин жана адам укугунун негизги принциптерин эске ацуу менен мамлекеттик жөнгө сацуу күчөтүлөт. Кыргыз Республикасынын Коргоо кеңешинин кезектеги жыйынында сүйлөгөн сөзү. 3.11.2014, „Эркин Тоо” 4.11.2014. 
Konstruowanie islamu jako zagrożenia egzystencjalnego dotyczyło w Azji Centralnej przede wszystkim trzech sektorów. W aspekcie militarnym miał on zagrażać przetrwaniu państwa, ludności, integralności terytorialnej, czy możliwościom wojskowym. W sektorze politycznym miał stwarzać niebezpieczeństwo zachowaniu suwerenności i stabilności porządku społecznego. W sektorze społecznym stanowił zagrożenie lokalnej, rdzennej kolektywnej tożsamości, języka i kultury. Skuteczny proces sekurytyzacji nie byłby zrealizowany bez sprzyjających mu warunków. W przypadku postkolonialnych, niedemokratycznych reżimów dużą rolę posiadał charakter, determinowanego przez mocarstwa światowe, środowiska międzynarodowego. Władze Azji Centralnej skorzystały z dominującego po wydarzeniach z 11 września 2001 r. dyskursu wojny z międzynarodowym terroryzmem. Sąsiedztwo z Afganistanem otwierało także perspektywę współpracy w wymiarze bezpieczeństwa z państwami zachodnimi. W konsekwencji pozwoliło to nie tylko osłabić zachodnią krytykę naruszania wolności i praw obywateli w państwach regionu, ale także uzyskać od nich wsparcie w wysiłkach legitymizacyjnych, konsolidacji systemów autorytarnych oraz przychylne przyjęcie w środowisku międzynarodowym.

\section{Bibliografia}

\section{Opracowania}

Balzacq T., A theory of Securitization: Origins, Core Assumptions, and Variants, [w:] Securitization Theory. How Security Problems Emerge and Dissolve, red. T. Balzacq, New York 2011.

Buzan B., Wæver O., de Wilde J., Security: A New Framework for Analysis, London 1998.

Buzan B., Wæver O., Regions and Powers: The Structure of International Security, Cambridge 2003.

Davenport C., Repression and Mobilization: Insights from Political Science and Sociology, [w:] Repression and Mobilization, red. C. Davenport, C. Mueller, H. Johnston, Minneapolis-London 2005.

Fijałkowski Ł., „Akt mowy” $i$ „język bezpieczeństwa” a konstruowanie glo- 
balnych zagrożeń (dyskursywne podejście do bezpieczeństwa), „Kultura - Historia - Globalizacja” 2013, nr 14.

Fijałkowski Ł., Teoria sekurytyzacji i konstruowanie bezpieczeństwa, „Przegląd Strategiczny” 2012, nr 1.

Karin E., The Soldiers of the Caliphate: The Anatomy of a Terrorist Group, Astana 2016.

Khalid A., Islam after communism. Religion and Politics in Central Asia, Berkeley 2007.

Lain S., Strategies For Countering Terrorism and Extremism in Central Asia, „Asian Affairs” 2016, vol. 47, nr 3.

Marczuk K., Bezpieczeństwo wewnętrzne w poszerzonej agendzie studiów nad bezpieczeństwem (szkoła kopenhaska i human security), [w:] Bezpieczeństwo wewnętrzne państwa: wybrane zagadnienia, red. S. Sulowski, M. Brzeziński, Warszawa 2009.

Matveeva A., Radicalisation and Violent Extremism in Kyrgyzstan. On the Way to the Caliphate? „The RUSI Journal” 2018, vol. 163, nr 1.

Matveeva A., Tajikistan: Revolutionary Situation or a Resilient state? „EUCAM Policy Brief” 2009, nr 12.

Montgomery D.W., Heathershaw J., Islam, Secularism and Danger: A Reconsideration of the Link Between Religiosity, Radicalism and Rebellion in Central Asia, „Religion, State and Society” 2016, vol. 44, nr 3.

Montgomery D.W., Practicing Islam: Knowledge, Experience, and Social Navigation in Kyrgyzstan, Pittsburgh 2016.

Musioł M., Kompleks Bezpieczeństwa w regionie Azji Środkowej po 1991 roku, Warszawa 2015.

Musioł M., Znaczenie sekurytyzacji i sektorów bezpieczeństwa w ramach krytycznych studiów nad bezpieczeństwem, „Historia i Polityka” 2018, nr 23 (30).

Omelicheva M.Y., Islam and Power Legitimation: Instrumentalisation of Religion in Central Asian States, „Contemporary Politics” 2016, vol. 22, nr 2.

Peoples C., Vaughan-Williams N., Critical Security Studies. An introduction, London-New York 2010.

Shukuralieva N., Azja Centralna: uwarunkowania integracji regionalnej, [w:] Relacje Unii Europejskiej z Azją Centralna. Uwarunkowania, wyzwania, efekty, red. T. Wallas, R. Fiedler, Poznań 2018. 
Shukuralieva N., Bezpieczeństwo międzynarodowe, terroryzm i zasoby naturalne. Międzynarodowa legitymizacja władzy w Azji Środkowej, „Sprawy Międzynarodowe” 2013, nr 4.

Shukuralieva N., Lipiński A., Legitymizacja władzy jako wielowymiarowy mechanizm stabilizacji systemu autorytarnego. Casus państw Azji Centralnej, [w]: Azja Centralna: tożsamość, naród, polityka, red. N. Shukuralieva, Kraków 2018.

Szalacha J., Sokołowicz W., Sekurytyzacja jako paradygmat $w$ badaniach nad bezpieczeństwem oraz proces polityczny. Koncepcja i konteksty, [w:] Za kulisami Szkice o wtadzy, interesach i bezpieczeństwie, red. K. Pietrowicz, P. Stankiewicz, Poznań 2013.

von Soest C., Grauvogel J., Identity, Procedures and Performance: how Authoritarian Regimes Legitimize their Rule, "Contemporary Politics” 2017, vol. 23, nr 3.

Vuori J.A., Illocutionary Logic and Strands of Securitization: Applying the Theory of Securitization to the Study of Non-Democratic Political Orders, „European Journal of International Relations” 2008, t. 14, nr 1.

Wæver O., Securitization and Desecuritization, [w:] On Security, red. R.D. Lipschutz, New York 1995.

Черных И., Бурнашев Р., Условия секьюритизации международного терроризма в Центральной Азии, „Connections. The Quarterly Journal" 2005, t. 4, nr 1.

International Partnership for Human Rights, The Danger of Standing up for Justice and Rights in Central Asia. Trends regarding the Protection of Civil Society in the Region in 2017, Brussels, 03.2018.

Masylkanova A., Radicalization in Kyrgyzstan is no Myth: Kyrgyzstan's Slow Arc Toward Islamization and Radicalization, "The Diplomat”, 22.06.2016.

Tajikistan 2017 Human Rights Report. Executive Summary, U.S. State Department. Bureau of Democracy, Human Rights, and Labor, Washington 2018.

\section{Źródła}

„Саяси партиялар туралы” Қазақстан Республикасының 2002 жылғы 15 шілдедегі № 344-II Заңы.

Атамбаев А., Аиний чөйрөдө абийир эркиндигинин жана адам уку- 
гунун негизги принциптерин эске алуу менен мамиекеттик жөнгө салуу күчөтүлөт. Кыргыз Республикасынын Коргоо кеңешинин кезектеги жыйынында сүй өггн сөзҮ. 3.11.2014, „Эркин-Тоо” 4.11.2014.

Атамбаев А., Светтик мамлекеттин артыкчымыгы - түрАҮY Аиний жамааттардын өкүмАөрүнүн, Аин туткандар менен эч кандай АинАи тутпагандардын кызыкчымыктарын тең салмакта сактай бимгендигинде. „Ислам азыркы светтик мамлекетте” эл аралык конференциясында сүйлөгөн сөзү. 28.09.2017, http://www.president. kg/kg/okujalar/zhanylyktar/10946_prezident_almazbek_atambaev_ svettik_mamlekettin_artikchiligi_trd_diniy_ghamaattardin_ kldrnn_din_tutkandar_menen_ech_kanday_dindi_tutpagandardin_ kizikchiliktarin_te_salmakta_saktay_bilgendiginde.

Каримов И.А., Бизни танлаган йўмимизАан хеч ким қайтароммайди. Шу йимнинг 12-13 май кунмари АнАижон шахриАа рўй берган воқеалар муносабати биман махамиий ва хорижий оммавий ахборот воситалари учун ўтказимган матбуот анжуманидаги баёнот ва мухбирларнинг савом арига жавоблар, [w:] И.А. Каримов, Ўзбек халқи хеч қачон, хеч кимга қарам бўммайди, Ж. 13. Тошкент 2005.

Каримов И.А., Бизнинг бош мақсаАимиз - жамиятни Аемократлашти-

риш ва янгимаш, мамлакатни модернизация ва ислох этишАир. Ўзбекистон Республикаси Омий Мажмиси Қонунчикик палатаси ва Сенатининг қўшма мажмисидаги маъруза, 28.01.2005, [w:] И.А. Каримов, Ўзбек хамқи хеч қачон, хеч кимга қарам бўммайди, Ж. 13. Тошкент 2005.

Каримов И.А., Империя Ааврида бизни иккинчи даражахи одамлар, Аеб хисоблашар эАи. «Независимая газета» (Москва) мухбирининг савом арига жавоблар. 14.01.2005, [w:] И.А. Каримов, Ўзбек халқи хеч қачон, хеч кимга қарам бўммайди, Ж. 13. Тошкент 2005.

Каримов И.А., Ўзбекистон хитойнинг ишончии Аўсти ва хамкори бўлган, бундан кейин хам шунАай бўлиб қомаАи. Хитой Хамқ Республикасига Аавлат ташрифи муносабати биман „Жэньминь Жибао” газетаси мухбирига беримган интервью, 25.05.2005, [w:] И.А. Каримов, Ўзбек хамқи хеч қачон, хеч кимга қарам бўммайАи, Ж. 13. Тошкент 2005. 
Кыргыз Республикасынын 12.06.1999 № 50 „Саясий партиялар жөнүнАө” мыйзамы, „Эркин-Тоо” 25.06.1999.

Назарбаев Н.Ә., Сындарлы он жыц, Ацматы 2003.

Рахмонов Э., Вемикий поэт и виАный общественный деятель. Выступление на торжественном собрании, посвящённом 90-летию со Аня рождения устода Мирзо Турсун-Заде. Аушанбе 27.10.2001, [w:] Э. Рахмонов, Независимость Таджикистана и возрожАение нации, t. 4, Аушанбе 2006.

Рахмонов Э., Воспитывать человека, гражданина, патриота. Речь на встрече с представителями интелмигенции страны, 20.03.2004, [w:] Э. Рахмонов, Независимость Таджикистана и возрождение нации, t. 5, Аушанбе 2006.

Рахмонов Э., Выступление на десятом саммите Организации Исламской Конференции. Куаха-Аумпур (Малайзия) 15-19.10.2003, [w:] Э. Рахмонов, Независимость Таджикистана и возрождение нации, t. 5, Аушанбе 2006.

Рахмонов Э., Нам нужен стабильный Афганистан. Интервью с корреспондентом „Независимой газеты” 1910.2001, [w:] Э. Рахмонов, Независимость Таджикистана и возрождение нации, t. 4, Аушанбе 2006. Рахмонов Э., Пианирование семьи - залог стабильного ее развития. Речь на общереспубликанском собрании по проблемам демографического развития и планирования семьи, Аушанбе 20.02.2002, [w:] Э. Рахмонов, Независимость ТаАжикистана и возрождение нации, t. 4, Аушанбе 2006.

Рахмонов Э., Поздравцение по случаю празАника ИАи Фитр. 24.11.2003, [w:] Э. Рахмонов, Независимость ТаАжикистана и возрождение нации, t. 5, Аушанбе 2006.

Рахмонов Э., Поздравцение со священным месяцем Рамазан. 24.10.2003, [w:] Э. Рахмонов, Независимость ТаАжикистана и возрождение нации, t. 5, Аушанбе 2006.

Рахмонов Э., Связь веков - преемственность поколений. АокмаА в честь Авенадцатой годовщины независимости Республики ТаАжикистан и 1000-летия великого таджикского поэта и мыслителя Носира Хусрава. 8.09.2003, [w:] Э. Рахмонов, Независимость ТаАжикистана и возрождение нации, t.5, Аушанбе 2006. 
Рахмонов Э., Экстремизм не пройАёт. Интервью с корреспондентом журнала „Мимлениум” 10.2001, nr 10, [w:] Э. Рахмонов, Независимость Таджикистана и возрождение нации, t. 4, Аушанбе 2006.

Ўзбекистон Республикасининг 26.12.1996 й. 337-I-сон „Сиёсий партиялар тўғрисиАа”ги Қонуни, „Народное слово”, 7.01.1997, nr 4 (1527).

\title{
Securitization of Islam in Central Asia
}

\begin{abstract}
The aim of the article is to analyse mechanisms of constructing Islam in the discourse and practices of undemocratic Central Asian countries. This objective will be accomplished through the references to securitization theory located within the framework of the constructivist paradigm. The major argument of the paper is that the discursive transformation of various dimensions of Islam's existence into a homogeneous threat to the security was an important securitizing move. Its relevance is related to the national and international level of legitimacy. The strength of the securitizing move results from the amount of resources of the authoritarian Central Asian elites as the dominant securitizing actors. In the first part, the text critically discusses the radicalization of Muslims in Central Asia thesis and the practices of the state structures towards Islam. In the next part it will present various manifestations and dimensions of the securitization of Islam in the discourse and practice of the incumbent elites in Central Asia countries.
\end{abstract}

Keywords: securitization, security, Islam, terrorism, radicalization, fundamentalism, Central Asia

\section{Секьюритизация ислама в Центральной Азии}

\section{Абстракт}

Целью статьи является преАставление способов конструирования ислама в Аискурсе и практике недемократических стран Центральной Азии. Аیя Аостижения поставленной цели была использована, находящаяся в рамках конструктивистской парадигмы, теория секьюритизации. Согласно статье, преобразование разАичных проявлений ислама в однородную угрозу многогранно понимаемой безопасности было важным секьюритизирующим Авижением. Важность этого акта была связана с национальным и меж- 
Аународным уровнем мегитимации. ОАнако его сима зависела от влияния авторитарных ресурсов центральноазиатских элит как Аоминирующих секьюритизирующих акторов. В начале статьи будут представ ены проблемы, связанные с убежАениями о раАикализации мусульман в Центральной Азии. БуАет также обсужАаться политика государств региона по отношению к исламу. В следующей части статья укажет разАичные проявления и аспекты секьюритизации ислама в Аискурсе и практике правящей элиты.

Кмючевые слова: секьюритизация, безопасность, ислам, терроризм, раАикализация, фундаментализм, Центральная Азия

dr Nartsiss Shukuralieva

Uniwersytet Kazimierza Wielkiego w Bydgoszczy

Instytut Nauk Politycznych

ul. ks. J. Poniatowskiego 12

85-671 Bydgoszcz

ns@ukw.edu.pl

ORCID ID: https://orcid.org/0000-0003-4046-9738 